\title{
Developing Computer-Based Test (CBT) to Improve Students' Achievement
}

\author{
1Ika Irawati, ${ }^{2}$ Ita Fitriati \\ 1,2STKIP Taman Siswa Bima, Bima, Indonesia \\ 1ikairawati@gmail.com, 2itafitriati88@gmail.com
}

\begin{tabular}{|c|c|}
\hline Article Info & bstract \\
\hline $\begin{array}{l}\text { Article History } \\
\text { Received: July 12, } 2018 \\
\text { Accepted: September 30, } \\
2018\end{array}$ & \multirow[b]{2}{*}{$\begin{array}{l}\text { This research aims to develop Computer-Based Test (CBT) by using hot } \\
\text { potatoes software, which is believed to be able to improve students' } \\
\text { achievement. Formative and summative questions were previously given } \\
\text { using paper only, making the questions presented less interactive, resulting } \\
\text { in low achievement of the students. This new procedure was adapted from } \\
\text { ADDIE Model (Analysis, Design, Development, Implementation, and } \\
\text { Evaluation). The development of the model results in the creation of a } \\
\text { package called Computer based Test-English Computer (CBT-EC) that } \\
\text { contains } 9 \text { sub-packages, divided into two divisions. The first division is } \\
\text { composed of } 8 \text { packages that contain formative tests, where as the second } \\
\text { division consists of } 1 \text { package of summative tests. Data of this research were } \\
\text { collected using tests and questionnaires. The test instrument used multiple } \\
\text { choices with formative form consists of } 15 \text { questions from each chapter, } \\
\text { while summative form consists of } 120 \text { questions. Students' responses were } \\
\text { measured by distributing the questionnaires about the usage of CBT-EC } \\
\text { product to } 10 \text { students. The questionnaires were given to the media expert } \\
\text { and material expert to assess their feasibility. The results showed that the } \\
\text { expert of material gave } 79 \text { out of } 84 \text { maximum point, or almost excellent, } \\
\text { meaning that the questionnaires developed as the product of CBT-EC are } \\
\text { worth implemented. Meanwhile, the assessment of the media expert gave a } \\
\text { score of } 63 \text { out of } 68 \text { maximum points classified as good, meaning that the } \\
\text { CBT-EC product is feasible to be implemented. Based on learning result from } \\
\text { the formative and summative test, there was an increase of the students' } \\
\text { achievement. In formative test, the students got the average score of } 69 \% \text {, } \\
\text { whereas in summative test they recorded average score of } 79 \% \text {. In } \\
\text { conclusion, CBT-EC product could increase students'achievement. }\end{array}$} \\
\hline $\begin{array}{l}\text { Keywords } \\
\text { Computer-Based Test (CBT); } \\
\text { Achievement; } \quad \text { Media; } \\
\text { Assessment }\end{array}$ & \\
\hline & \\
\hline
\end{tabular}

\section{INTRODUCTION}

Evaluation is one of the most important agenda carried out by lecturers to measure students' ability. Assessment is usually obtained from the test, the test can be oral or writing, interesting and interactive tests are very helpful in fostering student interest and passion to answer the questions. Evaluation has a purpose to improve the effectiveness of learning implementation and measure the students' achievements. There are several factors that affect the occurrence of error in measurement, those are: from the measuring instrument, from the evaluator, from the object (students) are assessed, and from the situation where the assessment took place. Therefore, teachers and lecturers are required to understand the nature of evaluation and skilled in selecting and conducting evaluations.

Based on the experience of teaching and observation that had been done by researchers in the field, the problems that were often faced by students were the 
interest of students very less in answering the questions. Students tended to be bored in answering the questions because of the appearance of a monotonous question and less interactive, thus making the students' achievements tended to be static and low. Generally, the form of questions provided only printed on papers and no change. Nowadays, is getting advanced so rapidly where learning media and modern evaluation media can be utilized in the learning process. One of the evaluation media that are available in today's technological era is Computer Based Test (CBT) which uses hot potatoes software to create interactive questions, this software can be downloaded on the internet for free for a limited version and paid version for unlimited access. Hot potatoes provide making some type of interactive web-based questions. In addition hot potatoes software is used to evaluate the questions easily in terms of spreading the questions, determinates the duration of time, randomizing the questions, examining the answers, and calculating the results automatically.

Based on the problem as described above, the researchers proposed a research title: "Development of Computer Based Test (CBT) for Improving Students' achievement"

\section{Design of CBT}

Computer Based Test (CBT) is a test used to measure learning achievement by using computer media. CBT is the most advanced innovation in the world of technology and information to measure students' abilities. The advantages of CBT include determination of the time duration of the exam and students no longer need to use paper and pens in the test, they simply sit quietly and answer questions which are available in the computer that is displayed on theme test in the monitor.

Computer based test (CBT) used in this research was Hot Potatoes software to carry out both training and test. The Hot potatoes software is a set of authoring tool, it was created by the Research and Development team at The University of Victoria Humanities Computing and Media Centre.

Hot Potatoes software is an evaluation software used for making interactive computer-based questioning which consists of six programs, namely: JQuiz, Jmix (Jumbled-sentence Exercise), Jcross (Crossword Puzzles), Jmatch (Matching and or Ordering Exercises), Jclose (Gap-fill Exercises), and The Masher (combined).

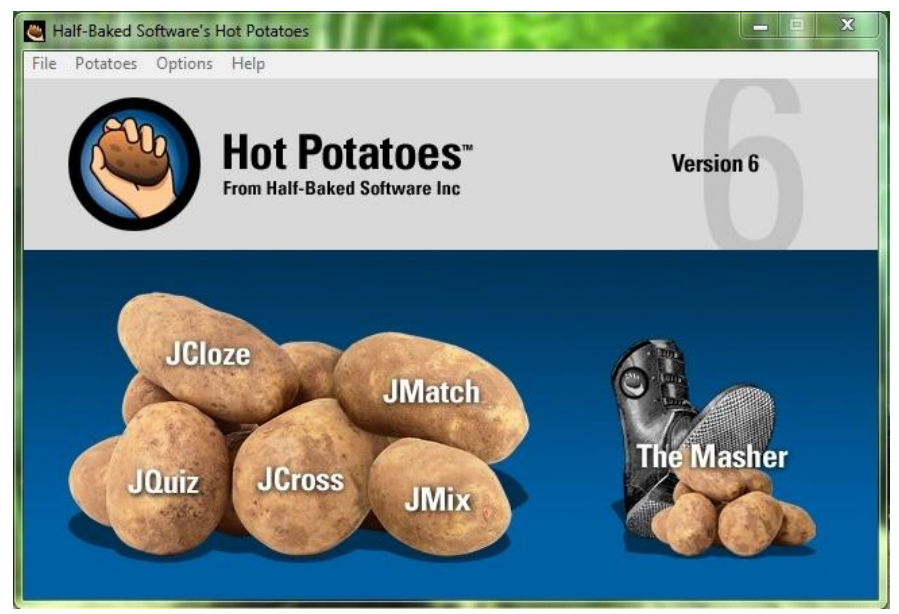

Interface Hot Potatoes Software Version 6

Hot Potatoes are used to create variety of interactive exercises then can be exported as web pages and launched in web browser. Students can correct their own work based 
on the clues and feedback set up in advance by the teacher and also automatic scoring is included in the exercises.

Five Hot Potatoes programs can be used freely by educational institutions, those are: JQuiz, Jmix (Jumbled-sentence Exercise), Jcross (Crossword Puzzles), Jmatch (Matching and or Ordering Exercises), dan Jclose (Gap-fill Exercises), while the last program is The Masher which is a complementary program that is designed to set some training content or questions that can be combined from the 5 free programs have already mentioned, The Masher can only be obtained by paying to get the serial number or license from the vendor. Teachers and lecturers can measure students' abilities by using this application either as formative test or summative test. This program can be obtained through the official address at http://www.halfbakedsoftware.com/hot_pot.php or via the address http://hotpot.uvic.ca, or can be downloaded at http://www.softpedia.com/get/Others /Home-Education/Hot-Potatoes.shtml which is the safest and trusted website application provider.

The JQuiz program is used to create question-based quizzes. Questions can be four different types including multiple-choice and short-answer. Specific feedback can be provided both for right answers or wrong answers in short-answer and multiple-choice questions.

JQuiz has 4 types of sub programs, those are: Multiple Choice, Short answer, Hybrid (a combination of questions from Multiple Choice and Short Answer, and Multi-select. Hot potatoes version that researchers used was Hot Potatoes V6 and multiple choice type of JQuiz sub-program of Hot Potatoes.

\section{Evaluation Measure Tool}

Scientifically speaking, evaluation is a systematic determination of a measure's merit and significance, using criteria governed by a set of standards. It is part of a continuing management process consisting of planning, implementation, and evaluation; ideally with each substituting the other in a continuous and simultaneous cycle until successful completion of the measure. In other words: evaluation tells you what really happened in your measure - compared to what should have - why it happened and what you can learn from these deviations. On top of that, evaluation will determine if you have reached your intended goals.

Evaluation is an independent, systematic investigation into how, why, and to what extent objectives or goals are achieved. It can help the Foundation answer key questions about grants, clusters of grants, components, initiatives, or strategy.[4, p. 3]

Based on the definition of the expert above, the researchers state that evaluation is a process to get the result about the objects assessed, so, that is why measuring students' abilities in the learning achievement assessment is very important education world, more specifically for education in college. In fact, the activity of measuring ability on the assessment process is to compare something or something else.

The researchers believe if evaluation tool which suitable is hot potatoes. It support the previous researchers who state that Hot Potatoes exercises have such advantageous technological use when they are accessed by learners as a complementary classroom assignment whether within or outside of the classroom settings. Hot Potatoes Interactive Web exercises can increase the interaction and motivate among learners and teachers.[5, p. 2413]

\section{METHOD}

In this study, the researchers used research and development $(\mathrm{R} \& \mathrm{D})$ method to produce and test the feasibility of the information technology-based products. The product was 
developed in the form of Computer Based Test-English for Computer (CBT-EC) by using Hot Potatoes software, product improvement process had been conducted and validated by the expert of material and the expert of media. After the $C B T-E C$ product was rated good and feasible by the expert of material and the expert of media, the researchers continued to the next stage, it was namely the stage of trial. The trial of product was conducted through two phases: small-scale trial and large-scale trial, small-scale trial had been conducted to evaluate the process of product quality and the quality of students' achievements. The test subject was the first semester student, amounting to 10 students. The results of small-scale test was to make some revision and refinements to the display or interface on the product $C B T-E C$ (Computer Based Test-English Computer), after it, the large-scale trials or field tests was conducted on the first semester student amounting to 80 students of English for Computer subject, the students were given Summative test which was contained 60 questions by 60 minutes of time duration. The purpose of field testing was to measure the improvement of students' achievements by using CBT-EC (Computer Based Test-English Computer).

\section{RESULT}

Computer Based Test-English Computer (CBT-EC) by using multiple choice type of Hot Potatoes software had 2 forms of evaluation questions, first, formative form test which contained 120 questions, this questions were summarized and made based on the material description that had been taught which amount of 8 chapters of discussion in English for Computer course. Second, summative form that was contained 60 questions by 60 minutes of time duration; these questions were taken randomly from formative questions. The spread of Summative test was conducted to measure the improvement of students' achievements by using Computer Based Test-English Computer (CBT-EC) product.

The students' responses from the questionnaire assessment that using and doing on the product by using Computer Based Test-English Computer (CBT-EC) was, on the presentation aspect of the material which consisted of 3 points of assessment, the average score of the students' answers is $93.3 \%$ per aspect, while Hot Potatoes Software consists of 5 points of assessment, the average score of student answers per aspect is $93.0 \%$. Assessment on aspects of the questions in $C B T$-EC consisting of 7 points of assessment, the average score of student answers per aspect is $91.4 \%$. The number of students who answered "strongly agrees" from all aspects was 104 while the number of students who answered "agree" is 46. The percentage result proved $69.3 \%$ answered "strongly agree" and 30.7\% answered "agree" of $100 \%$ total. Thus, from the questionnaire assessment that had been disseminated to the students' showed the $C B T-E C$ was "good" and "feasible" product to be implemented.

The process of revision and validation by the expert of media and the expert of material were done twice. 1 time was the process of improvement or revising the product and material while the second meeting was validation of the product, based on the results of revision and refinements of the product, CBT-EC was considered good and worthy to be tested. The assessment results of the expert of media who answered 17 assessment items, 12 items were answered "very good" while 5 other items were answered "good" category. So it could be concluded that the final product of Computer Based Test-English for Computer was categorized "Very Good" with a total points 63 (very good) from 68 (very good) maximum scores, it indicated that Hot Potatoes software was very feasible to be implemented to measure students' achievements. While the assessment of the expert of material based on the total of 21 questionnaires, 16 items were answered "very good" and 5 items were answered "good". It proved that the material of final product computer Based test was categorized "Very Good" which it got points 79 (very good) of 84 (very good) total points, it indicated that the material was very feasible to be implemented to measure students' achievements. 
CBT-EC product was implemented in two classes which contained 80 students on field test. Field test aimed to determine the improvement of students' achievements during one semester. There were much improvements of students' achievements of the formative and summative tests, the students got an average score on the first test of $63 \%$, the second test got $63 \%$, the third test gained $63 \%$, the fourth test got $63 \%$, the fifth test got $66 \%$, the sixth test got $77 \%$, the seventh test gained $82 \%$, and the eighth test got $78 \%$ on formative tests, so the average score of formative test was $69 \%$ by using hot potatoes, while the formative tests by using papers got average result of the first test was $43 \%$, the second test got $50 \%$, the third test gained $47 \%$, the fourth test got $39 \%$, the fifth test got $40 \%$, the sixth test gained $52 \%$, the seventh test got $46 \%$ and the eighth test got $42 \%$, so the average result of the formative was $45 \%$, so the difference percentage by using CBT-EC and paper was $24 \%$, it meant that using CBT-EC product could increase students' formative result tests. The summative test result by using CBT-EC was 79\% while the summative test by spreading the paper test was $50 \%$, so the difference of summative test results between Using CBT-EC and spreading paper was $29 \%$; it was proved if the using of CBT-EC could improve students' Achievements.

\section{CONCLUTION}

The assessment results of the expert of media who answered 17 assessment items, 12 items were answered "very good" while 5 other items were answered "good" category. So it could be concluded that the final product of Computer Based Test-English for Computer was categorized "Very Good" with a total points 63 (very good) from 68 (very good) maximum scores, it indicated that Hot Potatoes software was very feasible to be implemented to measure students' achievements.

The assessment of the expert of material based on material total 21 questionnaires, 16 items were answered "very good" and 5 items were answered "good". It proved that the material of final product computer Based test was categorized "Very Good" which it got points 79 (very good) of 84 (very good) total points, it indicated that the material was very feasible to be implemented to measure students' achievements.

There were much improvements of students' achievements of the formative and summative tests, the average score of formative test was $69 \%$ by using hot potatoes, while the average formative score by spreading paper was $45 \%$, so the difference percentage by using CBT-EC and paper was $24 \%$, it meant that using CBT-EC product could increase students' formative result tests. The summative test result by using CBTEC gained 79\% while the summative test by spreading the paper test got $50 \%$, so the difference of summative test results between Using CBT-EC and spreading paper was $29 \%$, it was proved if the using of CBT-EC could improve students' Achievements.

\section{REFERENCE}

[1] S. Arneil, Martin Holmes, and T. University., "Hot Potatoes," Half-Baked Software Inc., 2009. [Online]. Available: http://www.halfbakedsoftware.com/. [Accessed: 06-Jul2018].

[2] E. Setiawan, "The Use Of Hot Potatoes For Teaching Vocabulary At The Eleventh Grade Of SMA Bodhisattva," Fourth Int. Conf. Educ. Lang. (4th ICEL) 2016.Universitas Bandar Lampung (UBL), Indones., vol. ISSN 2303-, no. May, pp. 232-241, 2016.

[3] K. Dziekan, V. Riedel, and M. Stephanie, Evaluation Matters: A Practitioners' Guide to Sound Evaluation for Urban Mobility Measures. Münster / New York / München / Berlin: Die Deutsche Nationalbibliothek, 2013.

[4] Fay Twersky. F and K. Lindblom, "Evaluation Principles and Practices: An Internal Working Paper,” no. December, p. 30, 2012. 
[5] N. Sadeghi and H. Soleimani, "A Description and Evaluation of Hot Potatoes Webauthoring Software in Educational Settings," Theory Pract. Lang. Stud., vol. 5, no. 11, pp. 2407-2415, 2015. 